Síntese - Rev. de Filosofia

v. 37 N. 118 (2010): 243-266

\title{
SAMUEL PUFENDORF E O DISCURSO DOS DIREITOS
}

(Samuel Pufendorf and the Discourse of Rights)

Luiz Felipe Netto de Andrade e Silva Sahd*

Resumo: $O$ artigo apresenta algumas ideias importantes do discurso dos direitos de Samuel Pufendorf. Analisando cuidadosamente nas obras de Grotius e Hobbes, Pufendorf questionou e corrigiu uma série de detalhes e pontos importantes de seus antecessores. De Hobbes, Pufendorf questionou a falta de rigor na atribuição de direitos aos homens no estado de natureza. Ele indica também alguns limites das teses do Grotius, em especial quanto à expressão appetitus socialis. Pufendorf foi, portanto, um dos primeiros a perceber um aspecto importante dos direitos - ao menos dos direitos "verdadeiros" ou "propriamente ditos" -, que podemos chamar de correlatividade entre direitos e deveres (na ciência jurídica, esta concepção é especificamente conhecida como bilateralidade do direito). Nenhum direito pode ser atribuído a uma pessoa sem que se atribuam a outras, ao mesmo tempo, certos deveres correlativos de não-interferência. $O$ artigo também discute a resposta oferecida pelo tradutor e grande divulgador das obras de Pufendorf, Jean Barbeyrac, a Leibniz. Barbeyrac reprova a confusão promovida por Leibniz, ao misturar conveniência e obrigação, interesse e dever, e o fato de, por isso, não ter percebido que para Pufendorf há grande diferença entre ações úteis e ação moral. Palavras-chave: Estado de natureza, direitos, sociabilidade, soberania.

Abstract: This paper presents some important ideas of Samuel Pufendorf's discourse on rights. Analyzing carefully the works of Grotius and Hobbes, Pufendorf questioned and corrected a number of important points and details of his predecessors. Pufendorf questioned Hobbes' lack of rigor in his allocation of rights to men in the state of nature. He also points out some limitations of Grotius' theory, in particular the expression appetitus socialis. Therefore, Pufendorf was

* Departamento de Filosofia da Universidade Federal de Uberlândia/MG. Artigo submetido a avaliação em 26/01/2010 e aprovado para publicação em 15/07/2010. 
one of the first to realize an important aspect of rights - at least of "true" or "proper" rights- which we may call the correlativity of rights and duties (in legal science, this notion is specifically known as bilateralism of the Law). No right can be assigned to a person without, at the same time, attributing to others certain correlative duties of noninterference. The paper also discusses the answer given to Leibniz by Jean Barbeyrac, the translator and disseminator of Pufendorf's work. Barbeyrac deplored the fact that Leibniz confused convenience and obligation, and interest and duty, and by so doing failed to notice the great difference made by Pufendorf between useful actions and moral action.

Key words: State of nature, rights, sociability, sovereignty.

Introdução

$\mathrm{I}$ nstado a emitir julgamento sobre o De officio hominis et civis (1672) de Pufendorf, ${ }^{1}$ Leibniz não hesita nem um pouco na avaliação depreciati va da obra: há consideráveis "defeitos em seus princípios". ${ }^{2}$ Em páginas severas, o autor pretende mostrar que a razão é "a norma indubitável do direito natural" e os mandamentos emanados da vontade de um supe-

1 O Jugement d'un Anonyme apresenta um diálogo triangular entre Leibniz, o "autor anônimo", Pufendorf, o "nosso autor" e Barbeyrac, em sua própria voz na primeira pessoa. A história do texto é assim descrita por Barbeyrac: "Il m’est tombé entre les mains, depuis un an, ou environ, une Lettre Latine d'un Anonyme, dans laquelle il donne son jugement sur l'Original de cet Abrégé des Devoirs de l'Homme \& du Citoien. Cette Lettre, imprimée en MDCCIX, se trouve inseré dans un Programme Académique de Mr. Juste Christophle Böhmer, Professeur à Helmstadt, qui annonçoit là douze Disputes publiques qu'on devoit soûtenir, sur le Systême de Droit Naturel, que nôtre Auteur donne dans ce petit Livre" (BARBEYRAC, J., Jugement d'un Anonyme, in Les devoirs de l'homme et du citoien (trad. do latim de J. Barbeyrac) Hildesheim: Georg Olms Verlag, 1992, p.379). Barbeyrac desconfia do anonimato da carta, pois há vários indícios de leitores que conheciam o nome de seu autor. Não obstante, o próprio Barbeyrac reconhece que a intenção de Leibniz ao escrever a missiva era atingir o restrito público da academia, em especial o reduzido número de participantes do curso do professor Böhmer. A carta recebeu o título latino: Epistola Viri Excellentissimi ad Amicos, qua monita quaedam ad principia Pufendorfiani Operis De Officio Hominis \& Civis continentur.

${ }^{2}$ Leibniz o descreve desdenhosamente como Parum jurisconsultus et minime philosophus ("um jurisconsulto médio e um filósofo mínimo"). Cf. os comentários sugestivos de SAASTAMOINEN, K., The Morality of the Fallen Man. Samuel Pufendorf on Natural Law, Helsinki: SHS, 1995, p. 95-110, HOCHSTRASSER, T. J., Natural Law Theories in the Early Enlightenment, Cambridge: Cambridge University Press, 2000, p. 72-110 e HUNTER, I., Rival Enlightenments. Civil and Metaphysical Philosophy in Early Modern Germany, Cambridge: Cambridge University Press, 2001. Não é nossa intenção contrapor as perspectivas de Leibniz e Pufendorf, embora alguns trabalhos que se enveredaram por esse caminho demonstraram a riqueza do debate; penso nos trabalhos de BOBBIO, N., Leibniz e Pufendorf, in Da Hobbes a Marx, $2^{\mathrm{a}}$ ed. Napoli: Morano Editore, 1971, p. 129145; SÈVE, R., Leibniz et l'École moderne du droit naturel, Paris: PUF, 1989; SCHNEEWIND, J. B., Barbeyrac and Leibniz on Pufendorf, in PALLADINI, F. e HARTUNG, G. (Hrsg.) Samuel Pufendorf und die europäische Frühaufklärung. Berlin: Akademie Verlag, 1996, p.181-189; HUNTER, I., The love of a sage or the command of 
rior não podem constituir as regras da universal jurisprudência. Próximo de Grotius, Leibniz insiste no papel "das máximas da razão reta" que determinam a obrigação entre os homens e proporcionam, simultaneamente, a possibilidade de ordem e justiça no mundo. Não obstante a extrema severidade do julgamento pode-se dizer que o De officio não apresenta fundamentos sólidos em matéria de direito natural? $\mathrm{O}$ dictamen rationis seria a única chave interpretativa do universo jurídico não abrindo espaço para os desvios da versão dualística da natureza e da liberdade presentes na obra jurídica de Pufendorf, na sua definição de entia moralia? A aparente falta de coerência expressa nos "defeitos dos princípios" não esconderia de fato uma teoria do direito natural mais elaborada e refinada? Ao unir o conceito de direito natural ao regulamento previsto por Deus, Pufendorf não teria oferecido à teoria da obrigação a dimensão ética mais ampla do que a forma jurídica proposta por Leibniz? Em suma, ao recusar

\footnotetext{
a superior: the natural law doctrines of Leibniz and Pufendorf, in HOCHSTRASSER, T.J. e SCHRÖDER, P. (ed.) Early modern natural law theories. Contexts and Strategies in the Early Enlightenment, Dordrecht: Kluwer Academic Publishers, 2003, p. 169-193; KORKMAN, P., Voluntarism and moral obligation: Barbeyrac's defence of Pufendorf revisited, in Hochstrasser, T.J. and Schröder, P. (ed.), Early modern natural law theories. Contexts and Strategies in the Early Enlightenment, p. 195-225. A proposta aqui é mais limitada, embora alguns aspectos importantes permitissem avaliar o papel de Leibniz no debate do jusnaturalismo moderno, o alcance da renovação do racionalismo grotiano. É em torno da noção de qualitas moralis que Leibniz parece construir o conceito de direito e a teoria da obrigação: "Moralitas autem, seu Justitia, vel Injustitia actionis oritur, ex qualitate personae agentis in ordine ad actionem, ex actionibus praecedentibus orta, quae dicitur: Qualitas morais. Ut autem Qualitas realis in ordine ad actionem duplex est: Potentia agendi, et necessitas agendi; ita potentia moralis dicitur Jus, necessitas moralis dicitur Obrigatio" (LEIBNIZ, G. W., Philosophische Schriften 1. 1663 - 1672: Bd. 1, Berlin: Akademie Verlag GmbH, 2006, VI, 1, \$14 [a], p. 301). Próximo de Grotius, Leibniz, em seu Nova methodus, pensa o direito natural como qualitas moralis relacionada à pessoa da ação. Mas, diferentemente de Grotius, que propôs a noção de persona em sua definição do direito como qualidade moral, Leibniz parece ir mais longe ao nomear persona como subjectum: "Subjectum qualitatis moralis est persona et res. Persona est substantia rationalis, eaque vel naturalis vel civilis" (LEIBNIZ, G. W., Philosophische Schriften 1. 1663 - 1672: Bd. 1, VI, 1, §15, p. 301). De fato, ao fazê-lo, além de forjar o termo "sujeito de direito" (subjectum juris), Leibniz ofereceu uma caracterização do "direito subjetivo" mais bem fundamentada do que a apresentada por Grotius. Sobre Pufendorf, no entanto, René Sève insiste num ponto: Leibniz se opõe à visão normativa contida no $D e$ officio e defende uma concepção "finalista" cuja ação não pode ser avaliada em função da sua conformidade ou não à lei, "mais du bien (individuel ou collectif) auquel elle aboutit ou des intérêts qu'elle satisfait" (LEIBNIZ, G. W., Le droit de la raison, Textes réunis et présentes par René Seve, Paris: Vrin, 1994, p. 12). Para Sève, Pufendorf procura a "causa eficiente" do direito natural na vontade prescritiva de Deus, longe do mundo dos fatos, "alors que pour Leibniz, du fait qu'il existe une tendence naturelle de l'homme à se conserver et à augmenter sa puissance, et des rapports intelligibles entre les agents, il existe des relations morales" (ibidem, p. 13; cf. também SÈVE, R., Leibniz et l'École moderne du droit naturel, p. 59-63). Simone Goyard-Fabre insiste sobre o "ponto de vista individualista" de Leibniz, "qui relativise, d'une manière que l'on a pu qualifier d'utilitarisme, la portée du droit naturel” (GOYARD-FABRE, S., Pufendorf et le droit naturel, Paris: PUF, 1994, p. 33).
} 
a inserção do mundo moral no mundo físico e considerar redutora a ideia do mundo dos homens como sendo predeterminado, Pufendorf não seguiria o caminho da bilateralidade do direito cujo princípio de sociabilidade de que nascem o senso da obrigação e a responsabilidade apela também à noção ontologicamente fundada da liberdade? ${ }^{3}$ Se o sistema filosófico de Leibniz é marcado pela harmonia universal preestabelecida onde tudo é interdependente e solidário, em que a justiça assume então a figura de verdade eterna e, por sua fundação racional, conota no mundo o maior bem possível, Pufendorf defende o retorno à natureza objetiva das coisas que a razão tem apenas por tarefa discernir. Ele reprova o círculo vicioso da argumentação grotiana ao estabelecer na própria "razão as regras das máximas da Razão". ${ }^{4}$ Embora Pufendorf não negue o papel da lei natural como regra de orientação de cada um na qualidade de "animal racional", a razão não é a lei natural, "mas unicamente um meio de conhecê-la, se a colocamos em uso como é preciso". ${ }^{6}$ Jean Barbeyrac já havia percebido muito bem as diferenças em seu comentário do Jugement d'un Anonyme de Leibniz: as teorias do direito natural abrem dois caminhos divergentes

\footnotetext{
${ }^{3}$ De acordo com Richard Tuck, a teoria da correlatividade entre direitos e deveres tem por consequência que a linguagem separada dos direitos está perdida, pois todos os direitos podem ser expressos em termos de algum princípio maior de ordem moral. Assim, se não há uma linguagem verdadeiramente separada dos direitos, então há pouca margem para a autonomia ou a liberdade do indivíduo. Se, por outro lado, a teoria da correlação é falsa e, portanto, os direitos são conceitualmente independentes dos deveres, então nós podemos ter uma teoria moral ou política que afirma a soberania ou a autonomia do indivíduo (cf. TUCK, R., Natural Rights Theories. Their origin and development, Cambridge: Cambridge University Press, 1979). É nessa perspectiva polêmica que devemos interpretar a proposta de Pufendorf. Resumindo, ao contrário da interpretação proposta por Tuck, Thomas Mautner defende a tese segundo a qual Pufendorf parece reconhecer direitos sem que precisasse deveres correlacionados (MAUTNER, T., Pufendorf and the Correlativity Theory of Rights, in LINDSTRÖM, S. e RABINOWICZ, W. (eds.) In so Many Words: Philosophical Essays Dedicated to Sven Danielson on the Occasion of His Fiftieth Birthday, Philosophical Studies published by the Philosophical Society and the Department of Philosophy, University of Uppsala. №. 42 (1989) p. 37-59). Três argumentos são apresentado: “(i) For rights taken in the sense of deontic power, we have found that a correlated obligation comes into being only if the right is exercised. (ii) For rights taken in the sense of permission to receive something, we have found that there can be such rights although no other party is under an obligation to give. (iii) For the right to punish an offender (whether it be regarded as a permission or as a power) we have found that the offender is under no obligation to submit" (Ibidem, p.55). Defendo, porém, que nenhum direito pode ser atribuído a uma pessoa sem que se atribua a outras, ao mesmo tempo, certos deveres correlativos de não-interferência. E a pergunta sobre o direito de propriedade é o melhor exemplo. Mais adiante voltaremos ao assunto.

${ }^{4}$ PUFENDORF, S., Gesammelte Werke, Band 4.1: De jure naturae et gentium (Liber primus - Liber quartus), Herausgegeben von Frank Böhling, Berlin: Akademie Verlag, 1998, II, III, §23.

5 PUFENDORF, S., Gesammelte Werke, Band 4.1: De jure naturae et gentium (Liber primus - Liber quartus), II, III, §1.

${ }^{6}$ PUFENDORF, S., Gesammelte Werke, Band 4.1: De jure naturae et gentium (Liber primus - Liber quartus), II, III, §20.
} 
à normatividade, por um lado, busca-se a fonte na luz da razão, por outro, nos mandamentos da lei divina?

De qualquer modo, a recusa de Leibniz em reconhecer qualquer status filosófico à teoria do direito de Pufendorf, obriga-nos a compreender o peso do fato de que a própria ideia do direito natural pressupõe a possibilidade da filosofia no sentido pleno do termo. Ao mesmo tempo, obriganos a compreender a necessidade de uma reconsideração imparcial das premissas mais elementares cuja validade a filosofia pressupõe. No caso específico de Pufendorf, porém, a apresentação da teoria dos seres morais seria incontornável à intelecção do pensamento uma vez que a própria possibilidade da filosofia ali estaria pressuposta. Ressaltar a distinção entre os seres morais, objetos da ciência do direito, e os seres físicos, objetos da filosofia da natureza, permitiria encontrar o referencial filosófico em que se move Pufendorf, como dirimir os equívocos e acusações de insuficiências da sistematização do pensamento do autor. ${ }^{8}$

\footnotetext{
${ }^{7}$ Além disso, Barbeyrac também visualiza duas faces no estatuto filosófico do direito natural. $\mathrm{O}$ direito é perfeitamente cognoscível pela razão e está inserido no âmbito epistemológico do "conhecimento da natureza e da condição humana". Ou o direito natural é muito diferente do conhecimento de que é capaz a razão humana e requer a referência à "natureza das coisas" e das leis naturais divinas oriundas da criação original (cf. BARBEYRAC, J., 1992, p. 379-435; RILEY, P., Leibniz' Universal Jurisprudence. Justice as the Charity of the Wise, Cambridge, Mass.: Harvard University Press, 1996, p. 16-17). Segundo Goyard-Fabre: "A l'évidence, les positions de Leibniz et de Pufendorf sont inconciliables: d'après Leibniz, le 'monde moral' fait tout simplement partie du 'monde naturel' et appelle, dans une perspective de rationalité téléologique, l'amour pour Dieu; il en resulte que l'idée de rapports entre les volontés n'a pas de sens pour Leibniz: or, tout au contraire, l'idée que l'homme est capable, en tant qu'être moral, de volonté d'obéissance à la volonté de Dieu est l'idée maîtresse sur laquelle Pufendorf élabore sa théorie de l'obligation. Le divorce est consommé" (GOYARD-FABRE, S., Barbeyrac et la théorie du droit naturel, in BARBEYRAC, J., Écrits de droit et de morale, Paris: Thesaurus de philosophie du droit, 1996, p. 47; ver também KORKMAN, P., Voluntarism and moral obligation: Barbeyrac's defence of Pufendorf revisited, p. 200-203). Embora o tradutor das obras de Pufendorf para a língua francesa tenha recriminado um aspecto crucial de seu pensamento - neste ponto ele faz coro com Leibniz: o direito natural de Pufendorf aceita o ponto de vista de um ateu e exclui na sua dedução a imortalidade da alma e a possibilidade de os malvados serem punidos no Além (este ponto será retomado na conclusão do nosso artigo) -, Barbeyrac acerta na distinção inconciliável entre as duas tradições.

${ }^{8}$ Em suma, mostrar que a proposta de Pufendorf é bem mais sutil e complexa do que parece à primeira vista. Objeto do direito e das normas jurídica, a justiça é uma qualidade adquirida pelos homens não por meio da razão disso que é em si mesmo, a justiça divina, mas da razão daquilo que Deus quis para as suas criaturas morais: "ainsi la règle des actions droites n'appartient pas tout uniment à la nature des choses; l'obligation morale qui les commande répond à la volonté d'obéissance dont Dieu a voulu rendre capables les entia moralia" (GOYARD-FABRE, S., Barbeyrac et la théorie du droit naturel, in BARBEYRAC, J., Écrits de droit et de morale, p. 47).
} 


\section{A teoria dos entia moralia}

O que seriam os entia moralia? Não sem certa surpresa, Pufendorf define os seres morais como "os modos que modificam as substâncias de certa maneira". ${ }^{9}$ São realidades que dependem simultaneamente das vontades criadora de Deus ("primeiro autor dos seres morais") e dos homens. ${ }^{10} \mathrm{~A}$ finalidade deles é de aperfeiçoar as vidas humanas ao introduzir entre eles "uma harmonia bem regrada", isto é, conferir às vidas humanas valor que originariamente (por natureza) não possuíam. ${ }^{11}$ Desse modo, Pufendorf explica nos capítulos primeiro a quarto do livro primeiro do De jure naturae et gentium que os seres morais se formam por "instituição" (imposition): dependem da "vontade dos seres inteligentes" e "devem unicamente sua existência a determinação de seres livres". ${ }^{12}$ A origem deles não pode ser vislumbrada de "nenhum princípio interno" da substância das coisas, mas da criação humana que busca aperfeiçoar a natureza. Se as coisas são criadas, os seres morais são inventados. Eles não designam os homens em si mesmos, mas o que os homens são capazes de instituir enquanto conjugam os poderes da natureza e da liberdade. Segundo Pufendorf é nessa capacidade de instituição que reside a diferença fundamental entre os seres inteligentes, os homens, e os seres físicos determinados pela natureza. ${ }^{13}$

\footnotetext{
${ }^{9}$ Leonard Krieger observa: "What was characteristic here was Pufendorf's effort to have the best of both a dualistic and a monistic metaphysics, since He conceived the moral as a mode at once parallel to the physical and yet built upon it" (KRIEGER, L., The Politics of Discretion. Pufendorf and the acceptance of natural law, Chicago: The University of Chicago Press, 1965, p. 74).

${ }^{10}$ Segundo Franco Todescan, a distinção entre os seres morais criados por Deus e os seres morais temporalmente posteriores à existência do homem perfeitamente constituído (ex impositione hominum proveniunt) "finisce per porre il problema di un residuante, o meno, Wertobjektivismus" (TODESCAN, F., Le Radici Teologiche del Giusnaturalismo Laico. Il problema della secolarizzazione nel pensiero giuridico di Samuel Pufendorf, Milano: Giuffrè Editore, 2001, p. 20). Brufau Prats observa neste problema um "inadequado e pouco satisfatório" critério de moralidade. "En definitiva", comenta Brufau Prats, "su solución sigue una vía primordialmente subjetivista y no obtiene un adecuado y satisfactorio criterio de moralidade" (BRUFAU PRATS, J., La Actitud Metódica de Pufendorf y la Configuración de la "Disciplina Juris Naturalis", Madrid: I.E.P., 1968, p. 69).

${ }^{11}$ Cf. PUFENDORF, S., Gesammelte Werke, Band 5: Eris Scandica, Herausgegeben von Fiammetta Palladini, Berlin: Akademie Verlag, 2002, Epistola ad Scherzerum, p. 59-68. 12 A tradução do termo latino imposition por "institution" foi proposta por Barbeyrac (PUFENDORF, S., Le droit de la nature et des gens (trad. do latim de J. Barbeyrac) Caen: Presses Universitaires de Caen, 1989, I, I, §4, p.4). Ver a nota explicativa do tradutor em que ele justifica a dificuldade para encontrar um termo equivalente para a língua francesa da palavra latina imposition.

${ }^{13}$ Em outras palavras: são entidades morais ontologicamente diferentes das entidades físicas. Estes são efeitos das causas físicas cujo Criador é a causa primeira. Aqueles surgiram por imposition. É um ato de vontade realizado por uma autoridade superior. A imposition de Deus cria um tipo especial de ser moral: a obrigação moral. Sua vontade, expressa geralmente em leis, ou regras de conduta, determina as nossas obrigações morais. Mas, considerados como partes simples da natureza, como entidades físicas objetos com suas propriedades e eventos e ações com suas causas e efeitos -, são moral
} 
Apesar da independência que manifestam os homens ao inventarem entia moralia como expressão da liberdade em ato, as realidades morais "não subsistem por si mesmas", pois são "modos" variáveis da "substância" que ganham existência em virtude da impositio. Pufendorf diz: "São [entia moralia] modos que os seres inteligentes vinculam às coisas naturais ou aos movimentos físicos, com a finalidade de dirigir e restringir a liberdade das ações voluntárias do homem e para colocar alguma ordem, conveniência e bondade na vida humana". ${ }^{14}$ Assim, enquanto a finalidade dos seres

mente indiferentes. Segundo Hans Welzel, o mundo da cultura é o mundo dos entia moralia que, "sulla base del mondo degli enti fisici, ma sostanzialmente diverso da questo, conferisce direzione e scopo alle libere azioni dell'uomo ed in tal modo plasma la vita umana in una realtà determinata nel suo significato e nel suo valore" (WELZEL, H., La Dottrina Giusnaturalistica di Samuel Pufendorf. Un contributto alla storia delle idee dei secoli XVII e XVIII (trad. italina di V. Fiorillo) Torino: G. Giappichelli Editore, 1993, p. 46). Desse modo, para Palladini as duas únicas maneiras pelas quais os seres humanos podem instituir entia moralia são: adotando leis e realizando contratos (PALLADINI, F., I Meriti di Pufendorf nell'etica e la sua teoria degli enti morali, in FERRONATO, M. (org.) Dal "De Jure Naturae et Gentium" di Samuel Pufendorf alla Codificazione Prussiana del 1794, Padova: CEDAM, 2005, p. 112).

14 PUFENDORF, S., Gesammelte Werke, Band 4.1: De jure naturae et gentium (Liber primus - Liber quartus), I, I, § 3. Cf. a respeito o sugestivo comentário de Horst Denzer: "Es ist zu beachten, daâ Pufendorf hier Natur im Gegensatz zu Moral begreift, beide Dinge kommen aber in der menschlichen Handlung zusammen, die Verbindung von Natur und Moral ist also spezifisch für die menschliche Natur. Mit der Lehre von den entia moralia grenzt Pufendorf nicht nur den Bereich des menschlichen Handelns aus, sondern das menschliche Handeln wird dadurch auch wissenschaftlich analytisch segmentiert" (DENZER, H., Moralphilosophie und Naturrecht bei Samuel Pufendorf. Eine Geistes - und wissenschaftsgeschichtliche Untersuchung zur Geburt des Naturrechts aus der praktischen Philosophie, Müchen: C. H. Beck, 1972, p. 68). Na mesma linha, cf. o texto de Thomas Behme (BEHME, T., Samuel Pufendorf: Naturrecht und Staat, Göttingen: Vandenhoeck \& Ruprecht, 1995, p. 50-56). Principal defensor da influência aristotélica em Pufendorf, Denzer - neste caso ele é seguido por Behme - retira algumas conclusões significativas da teoria dos entia moralia cujo impacto na teoria da obrigação são evidentes. Denzer explica a justeza das razões do superior em termos de natureza racional e social do homem e do papel do Estado no cultivo ou conclusão desta natureza. Pelo seu papel no aperfeiçoamento da natureza moral do homem, o próprio Estado receberia como "consequência final" a determinação característica da moral natural: "Daâ die Natur des Menschen den Staat fordert, dazu gehören bei Pufendorf also Bedingungen. Der Begriff Natur muâ in seiner teleologischen Bedeutung genommen werden, nämlich daâ der Mensch nicht seinen natürlichen Neigungen und Leidenschaften frönt, sondern nach Vollkommenheit strebt. Der Staat ist deshalb natürlich als letzte Konsequenz der Kulturfähigkeit menschlicher Natur" (DENZER, H., Moralphilosophie und Naturrecht bei Samuel Pufendorf, p. 163). Para Denzer as razões do superior prevaleceriam apenas na medida em que seus comandos para o tipo de sociedade em que as faculdades racionais e sociais do homem podem ser aperfeiçoadas, mas não o contrário. Nesse sentido, Denzer interpreta a versão de Pufendorf do contrato social - acordo entre os indivíduos que possuem direitos naturais para o desenvolvimento de cada um -, como aquela que estabelece os direitos e obrigações recíprocas e a política soberana que deve ser obedecida na medida em que desenvolve a natureza moral de consolidação desses direitos. Em sentido diverso, Jerome B. Schneewind defende o papel antecipador da teoria de Pufendorf, mais exatamente da sua influência sobre o pensamento de Kant (SCHNEEWIND, J. B., Pufendorf's Place in the History of Ethics, in Synthese, 72 (1987) p. 142). Na mais

Síntese, Belo Horizonte, v. 37, n. 118, 2010 
físicos é a perfeição no mundo material e sensível, a ideia dos seres morais não possui outro sentido além da convicção de que o efeito moral das instituições é a própria perfeição da vida humana. Os homens são capazes de acrescentar à natureza, pela impositio de sua vontade, uma dimensão cultural que expressa sua liberdade em ato e os caracteriza como seres morais. Assim, pelo efeito da vontade inventiva e criadora - legado de Deus - a especificidade da natureza humana é se abrir ao horizonte de sentido e de valor para além da simples natureza, embora sem desafiar as suas forças imanentes. Mais exatamente, a conjunção das duas nobres faculdades (entendimento e vontade) faz do homem um ser livre, capaz de se adaptar a regras que inventa para si mesmo. ${ }^{15}$

Os entia moralia enquanto considerados substâncias são chamados de "pessoas morais". ${ }^{16}$ Pufendorf entende por isso "os homens considerados

importante das leituras neo-kantiana, Schneewind não interpreta a justeza das razões do superior em termos de realização de um bem natural, mas em termos de autonomia da faculdade racional responsável pela emissão de leis: "Pufendorf is here saying that the good God intended us to achieve with our special nature is not restricted to natural good. It must include a good indicated by the higher aspect of our nature - reason and will" (SCHNEEWIND, J. B., The Invention of Autonomy: A History of Modern Moral Philosophy, Cambridge: Cambridge University Press, 1998, p. 125). Salientando o caráter nãoteleológico da concepção de Pufendorf dos entia moralia, Schneewind trata os comandos do superior como antecipações da auto-legislação da razão (self-legislating reason) de Kant, atribuindo a sua justeza à maior parte racional da natureza humana de que são originários. Nesta visão, apenas o reconhecimento da maior fonte racional dos comandos do superior deve ser suficiente para criar a sensação de obrigação: "Here Pufendorf seems to be suggesting that simple recognition that a Law is a divine command should awaken a motive for compliance in us" (SCHNEEWIND, J. B., The Invention of Autonomy: A History of Modern Moral Philosophy, p. 137). Como resultado, Schneewind trata o recurso de Pufendorf às sanções políticas como o resultado de sua incapacidade de compreender como a própria razão pode impor obrigações políticas, atribuindo esse fracasso teórico à incapacidade de Pufendorf para conciliar as entidades morais e os seres físicos: "Obligation is a moral entity. As such it hás no causal Power of its own. Desires, as part of our physical nature, can cause us to act in space and time; but recognition of obligation gives us a consideration or reason for action that does not operate in the field of force in which desires operate" (SCHNEEWIND, J. B., The Invention of Autonomy: A History of Modern Moral Philosophy, p. 138; pode-se notar aqui a crítica de Leibniz endereçada a Pufendorf). Aparentemente, só com o advento da formulação kantiana da doutrina da autolegislação da razão foi possível apresentar uma explicação definitiva da justeza dos comandos do superior.

${ }_{15}$ Cf. PUfEndoRF, S., Gesammelte Werke, Band 5: Eris Scandica, Specimen contraversiarum, V, §1, p. 165; HUNTER, I., Rival Enlightenments, p. 164-165.

${ }^{16}$ Como bem lembra Milton Meira do Nascimento: "gradualmente, na teoria de Pufendorf, passamos das coisas morais para as pessoas morais e, destas, para as ações morais, fechando pois o mundo da instituição" (NASCIMENTO, M. M., O preço das coisas e a estima das pessoas em Pufendorf, in Cadernos de Ética e Filosofia Política 1, São Paulo (1999) p. 49). Fiammetta Palladini também ressalta esta gradual passagem: enquanto qualidade, as pessoas morais são ou formais (por exemplo, os títulos honoríficos) ou operativas (tendem a um ato ou operação). Na condição de qualidades morais operativas elas dividem-se em ativas ou passivas: são potestas, jus, obligatio (PALLADINI, F., I Meriti di Pufendorf nell'etica e la sua teoria degli enti morali, p. 105, cf. também WELZEL, H., La Dottrina Giusnaturalistica di Samuel Pufendorf, p. 56). 
em relação ao seu estado moral, ou ao emprego que eles ocupam na sociedade, como cada homem particular, como vários, reunidos por algum vínculo moral, compondo em conjunto uma única e mesma ideia". ${ }^{17}$ Desse modo, há duas espécies de pessoas: as pessoas simples e as pessoas compostas. As pessoas simples são públicas ou privadas conforme seus empregos se relacionem imediatamente à vantagem comum da sociedade civil ou ao bem particular de cada um dos membros de que ela é formada. As pessoas públicas, por sua vez, conforme os usos dos povos cristãos se dividem em pessoas políticas e pessoas eclesiásticas. Uma categoria particular de pessoa pública é aquela das pessoas ditas "representativas", tais como os embaixadores, os vigários, os síndicos, etc. Quanto às pessoas privadas, continua Pufendorf, elas são os cidadãos simples.

As pessoas morais compostas são formadas "quando vários indivíduos humanos se unem de maneira tal que o que querem ou o que fazem, em virtude desta união, representa uma única vontade e uma única ação". São as sociedades que, do mesmo modo das pessoas simples, se dividem em pública e privada. ${ }^{18}$

Pufendorf não deixa de indicar como são destruídos os entia moralia. Os seres morais produzidos pela instituição divina não podem ser aniquilados a não ser pela vontade do criador, Deus. Em compensação, os seres morais que surgem da vontade humana podem ser abolidos, por um efeito desta mesma vontade, sem que a substância física das pessoas ou coisas sofra a menor mudança. A substância permanece inalterada: quando um nobre sofre uma ofensa degradante, por exemplo, ele perde unicamente os direitos nobiliários e jamais as características essências advindo da natureza. ${ }^{19}$ Ele permanece homem, mas não mais um gentil.

Dessa maneira, os seres morais são definidos como modos. Eles representam "os modos de ser" da coisa e, como vimos, são dotados de três características principais: a) são "acréscimos" (superadditi) aos movimentos físicos; b) são impostos por certos seres inteligentes; c) os seus efeitos devem regular a liberdade dos atos humanos voluntários. Dividindo os seres morais em estado, pessoa, qualidade e quantidade, Pufendorf propõe as condições gerais do enquadramento de certas ações humanas e a multiplicidade dos seres que se relacionam mutuamente. Poder-se-ia traduzir entia moralia como valores: "são os conteúdos morais da consciência, que, enquanto

\footnotetext{
${ }_{17}$ PUFENDORF, S., Gesammelte Werke, Band 4.1: De jure naturae et gentium (Liber primus - Liber quartus), I, I, § 12 .

${ }_{18}$ PUFENDORF, S., Gesammelte Werke, Band 4.1: De jure naturae et gentium (Liber primus - Liber quartus), I, I, § 13.

${ }_{19}$ PUFENDORF, S., Gesammelte Werke, Band 4.1: De jure naturae et gentium (Liber primus - Liber quartus), I, I, § 23.
} 
estabelecidos e reconhecidos, constituem a consciência de cada um, determinando, dessa forma, um código universal da conduta humana". ${ }^{20}$

Por fim, distingue-se também o estado de natureza (status naturalis) e o estado acessório (status adventitius), que corresponderia aqui ao estado moral propriamente dito. Esta distinção permitirá compreender também a condição humana em oposição à condição animal. Como persona moralis, o homem tem condições de impor-se entia moralia, concretizando-as em ações livres. Ações morais que respondem ao princípio de imputation cujo equivalente não pode ser encontrado na natureza e é fundamental em matéria de moral, pois significa que "somos responsáveis por todas as ações cuja existência ou não estão em nosso poder". ${ }^{21}$ São ações especificamente humanas. ${ }^{22} \mathrm{E}$ enquanto tais, nós podemos "agir ou não agir, suspender nossos movimentos e regulá-los como acharmos apropriado". ${ }^{23}$ Os animais, por sua vez, estão presos à lógica da repetição puramente instintiva que as leis da natureza impõem conforme as regras do determinismo causal. Às suas ações não recaem as regras da imputação e responsabilidade morais. Os animais não são livres para agir, são criaturas que "seguem unicamente as impressões da natureza". ${ }^{24}$

\section{Os discursos dos direitos}

Em carta a Boinebourg de 1663, Pufendorf menciona que são possíveis duas vias para dar ao direito uma forma científica, ou a se utiliza a via da matemática, ou a via requerida pelo estudo da natureza. $\mathrm{O}$ autor rejeita o segundo método julgando-o incerto e impraticável no campo jurídico onde

\footnotetext{
${ }^{20}$ SCHMIDT-BIGGEMANN, W., Samuel von Pufendorf - Filosofia do Estado e do direito entre o barroco e o Iluminismo, in KREIMENDAHL, L. (org.) Filósofos do Século XVII (trad. de B. Dischinger) São Leopoldo: Editora Unisinos, 2003, p. 164.

${ }^{21}$ PUFENDORF, S., Gesammelte Werke, Band 4.1: De jure naturae et gentium (Liber primus - Liber quartus), I, V, §5.

${ }^{22}$ Segundo Simone Goyard-Fabre: "les analyses que donne Pufendorf de l'imputabilité des actions morales e de la responsabilité des agents moraux montrent qu'il s'agit bien pour lui de cerner la place et le sens de la liberté par rapport à la nature et, partant, d'ouvrir le monde humain à horizon axiologique qui, sans défier les forces immanentes de la nature, en indique l'insuffisance dès que l'on s'interroge sur ce que les choses humaines ont de spécifique" (GOYARD-FABRE, S., Pufendorf et le droit naturel, p.55). Em nota, Goyard-Fabre também chama a atenção para o fato da perseguição do prazer não pertencer ao rol das ações morais, mas sim do movimento natural das coisas. "Pufendorf est parfaitement clair: ce qui fait la moralité du choix dont la liberté a la charge n'est pas qu'il s'oppose au plaisir, mais qu'il recherche le bien dans la mesure où il concerne les rapports entre les hommes" (ibidem, nota 8).

${ }_{23}$ PUFENDORF, S., Gesammelte Werke, Band 4.1: De jure naturae et gentium (Liber primus - Liber quartus), I, I, §2.

${ }_{24}$ PUFENDORF, S., Gesammelte Werke, Band 4.1: De jure naturae et gentium (Liber primus - Liber quartus), I, I, §2.
} 
os costumes costumam contrariar as prescrições do direito natural. No De jure naturae et gentium (1672) ele ainda faz elogios aos méritos da dedução matemática e do método cartesiano, mas salienta a importância dos dois parâmetros epistemológicos que não foram levados em consideração até então. O primeiro parâmetro diz respeito à irredutível diferença ontológica entre entia moralia e entia physica. Parâmetro infelizmente, explica Pufendorf, nem sempre considerado por autores que trataram temerariamente os corpos morais como corpos naturais. Segundo aspecto relevante a ser considerado é que Pufendorf não assimila em absoluto o princípio fundamental do direito natural a um postulado euclidiano, embora não renuncia a construção racional do sistema. O princípio euclidiano não pode ser exposto senão depois de se ter observado e analisado a condição do homem no estado de natureza. O método racional e a pesquisa experimental devem ser complementares. As duas correntes antagônicas do direito natural convergem e Pufendorf utiliza ambos os métodos, o racional-dedutivo e o empírico-indutivo, para revelar o seu desejo de "metodologicamente cavalgar sobre a investigação empírico-histórica e sobre conceitos e proposições axiomáticas". ${ }^{25}$ Por um lado, Pufendorf é enfático ao dizer que seu princípio de direito natural não é um axioma imediatamente evidente, mas conhecido pela observação. Por outro, ele também se pronuncia abertamente pelo racionalismo inaugurado por Descartes que, partindo de princípios certos, busca chegar a proposições certas por via da demonstração correta, e construir com isso uma vera et solida scientia. ${ }^{26}$

25 BRUFAU PRATS, J., La Actitud Metódica de Pufendorf y la Configuración de la "Disciplina Juris Naturalis", p. 94.

${ }^{26}$ BRUFAU PRATS, J., La Actitud Metódica de Pufendorf y la Configuración de la "Disciplina Juris Naturalis", p.80-81. Para uma explicação mais detalhada das fontes do dualismo metodológico presente em Pufendorf, a obra seminal de Hans Welzel ainda é a melhor referência (cf. WELZEL, H., La Dottrina Giusnaturalistica di Samuel Pufendorf, p. 33-43). O comentador alemão descreve assim o impacto da recepção das duas tradições: "Egli conosce due specie di principi, il razionale e lo sperimentale; denomina i primi assiomi, i secondi osservazioni. La verità, la certezza e la necessità degli assiomi scaturisce dalla ragione stessa, senza percezione o apprendimento dedutivo dei fenomeni singolari, ma soltanto attraverso un'esame intellettuale. La certezza delle osservazioni emerge dal confronto e dalla percezione dei fenomeni singolari, tra loro costantemente corrispondenti" (Idem, p. 38). Nesse sentido, a tese crítica de Hans Kelsen acerca do direito natural moderno apresenta pouca consistência, embora sustente os dois planos de argumentação: a difícil conciliação entre os planos do "ser" e do "dever ser", que levou ao impasse teórico do direito natural moderno e à prevalência do positivismo jurídico, mais exatamente: a obliteração da "diferença essencial que existe entre as leis científicas da natureza, as regras pelas quais a ciência da natureza descreve seu objeto, e as regras por meio da quais a ética e a jurisprudência descrevem seus objetos, que são a moralidade e o Direito" (KELSEN, H. O que é justiça? (trad. de L. C. Borges) São Paulo: Martins Fontes: 1997, p. 139). A pretensão de "cientificidade" dos jusnaturalistas modernos deve ser relativizada (cf. SÈVE, R., Leibniz et l'École moderne du droit naturel, p. 9), pois em nenhum momento o projeto moderno de uma moral com "fundamentos inabaláveis" (omnino ejusmodi fundamentis nititur, PUFENDORF, S., Gesammelte Werke, Band 4.1: De jure naturae et gentium (Liber primus - Liber quartus), I, II, §4) pretendeu na ética e na jurisprudência o status que a ciência no século XVII alcançou no conhecimento das leis naturais.

Síntese, Belo Horizonte, v. 37, n. 118, 2010 
Em suma, Pufendorf aparece como um voluntarista que reconhece a autoridade da razão e, ao mesmo tempo, um racionalista que sabe atribuir o justo peso aos dados da experiência. A razão permaneceria abstrata se não pudesse apoiar-se sobre a natureza da coisa que formou a experiência do homem; mas a natureza da coisa remete, por sua vez, à vontade divina que a criou deste modo e não de outro.

A lei fundamental deve ser deduzida do estudo da condição humana, da experiência que põe a descoberta no homem as tendências contrárias que o agitam: amor sui, imbecillitas e pravitas animi, que o inclinam a prejudicar os outros, e a vontade de superar essa fraqueza constitutiva. $\mathrm{O}$ exame da realidade humana é necessário para o estabelecimento dos direitos, para a sua sistematização. O homem é concebido e afirmado como fonte de suas representações e de seus atos. O direito natural moderno será um direito subjetivo, criado e definido pela razão humana, no caso do racionalismo jurídico, ou pela vontade humana, no caso do voluntarismo jurídico, e não mais um direito objetivo, inscrito em qualquer ordem imanente ou transcendente do mundo. Aplica-se ao direito a convicção de que o homem é o princípio de toda normatização. ${ }^{27}$ Em outros termos, afirmando o princípio fundamental da socialitas, proposição obtida pela observação da natureza do homem, Pufendorf a torna fonte radical de onde podem subsumir-se todas as demais proposições de direito natural. ${ }^{28}$ Assim, da socialitas Pufendorf deduziu os princípios do direito, produzindo "o primeiro sistema autêntico de teoria geral do Direito", correspondente ao quase contemporâneo "sistema ontológico de Spinoza e ao de

\footnotetext{
${ }^{27}$ No capítulo do De Jure Naturae et Gentium dedicado às leis naturais, por exemplo, Pufendorf explica que o homem, refletindo sobre a sua natureza e constituição física, descobre imediatamente e de modo claro e evidente a necessidade de por um freio à ilimitada liberdade de que possui no estado de natureza. A liberdade aqui se revela ao mesmo tempo inútil e danosa. Para cumprir tal finalidade, porém, ele precisa recorrer à razão, a qual impõe as leis naturais, formulando assim a regra básica do agir humano. As leis naturais fundamentais que orientam o homem no estado de natureza - que permitem deduzir todas as normas práticas - nos impõem: primeiro, o respeito à pessoa do outro ("ninguém deve ofender os outros salvo se é provocado"); segundo, o respeito à propriedade de outrem ("a cada um deve ser permitido usufruir seus próprios bens"); terceiro, o respeito aos pactos ("cada um deve manter a promessa empenhada"); e quarto, o respeito aos interesses alheios ("cada um deve promover com ânimo feliz a vantagem de outrem nos limites do possível e segundo as obrigações mais rigorosas que nos atribuímos") (PUFENDORF, S., Gesammelte Werke, Band 4.1: De jure naturae et gentium (Liber primus - Liber quartus), II, II, §9). A fundação racional das leis naturais não comporta, todavia, uma solução inata, aliás, duramente criticada por Pufendorf: as leis naturais não são, portanto, impressas na mente do homem no instante de seu nascimento, mas, ao contrário, é o produto de uma reflexão madura e dependem de um processo árduo de aprendizagem (cf. PUFENDORF, S., Gesammelte Werke, Band 4.1: De jure naturae et gentium (Liber primus - Liber quartus), II, III, §13).

28 BRUFAU PRATS, J., La Actitud Metódica de Pufendorf y la Configuración de la "Disciplina Juris Naturalis", p.101.
} 
Newton" ${ }^{29}$ Assim, Pufendorf simultaneamente reconhece a autoridade da razão e atribui grande importância aos dados da experiência.

Em geral, o jusnaturalismo moderno é unânime no combate da ideia de um direito de natureza que seria potência ou força. Esse combate fica ainda mais explícito nos textos de Pufendorf. Contra Hobbes, o autor saxão se junta a Grotius na ideia de uma qualidade moral que se avalia no homem em vista de sua natureza racional, recusando assim ao direito natural uma potência física quantificável. Esta recusa é ainda mais explícita nas páginas do De jure naturae et gentium que examinam a concepção de Spinoza formulada no capítulo XVI do Tratado Teológico-Político. ${ }^{30} \mathrm{Na}$ visão de Pufendorf, a definição ali contida acabaria por sugerir o princípio da destruição do direito natural, pois o termo "direito" não significaria uma lei sobre a qual deveríamos nos regrar, mas unicamente a faculdade de agir. Haveria também uma temerária redução do direito ao poder físico. Na perspectiva de Pufendorf, ao fazer do direito uma qualidade física mediante a qual cada coisa produz as suas operações de modo único e determinado, o próprio conceito de direito encontrar-se-ia estendido ao conjunto dos seres que povoam a terra, compreendendo assim todos aqueles que são desprovidos da razão. O direito perderia a consistência ao deixar de designar a qualidade moral unicamente aos seres morais. $\mathrm{O}$ direito como qualidade física de indivíduos físicos inviabilizaria, portanto, a noção mesma de direito.

Recuperar a tradição inaugurada por Pufendorf e situá-la no contexto histórico da sua manifestação, portanto, seria o modo mais adequado a plena compreensão do impacto produzido pela utilização da linguagem dos direitos para pensar a política em pleno século XVII. Se a Guerra dos Trinta Anos moldou os discursos políticos de Grotius e Hobbes, perpassando as falas com as reivindicações dos direitos, foi o Tratado de Vestefália que instituiu na Europa o sistema de Estados soberanos no interior do qual reinava uma paz ainda relativa. O desafio lançado pelos signatários do acordo que pôs fim ao conflito religioso em 1648 foi imediatamente assumido por Pufendorf. Se o autor buscou equilibrar dois extremos no exame do homem na natureza, ${ }^{31}$ quando se volta à prática dos Estados nas relações internacionais, ele decisivamente favoreceu e recomendou prudência

\footnotetext{
${ }^{29}$ WIEACKER, F., Privatrechtsgeschichte der Neuzeit unter besonderer Berücksichtigung der deutschen Entwicklung, Göttingen: Vandenhoeck \& Ruprecht, 1996, p. 183.

${ }^{30}$ SPINOZA, B., Trattato teologico-politico, Edição bilíngue. Introdução, tradução e notas de Alessandro Dini, Milano: Bompiani, 2004, p. 516-547.

${ }^{31}$ Nem Aristóteles, nem Hobbes, mas um equilíbrio entre os dois perfis, eis a tese de Brufau Prats: "Estas mismas referencias de Pufendorf, repetidas luego en su obra capital, nos muestram un hecho decisivo: el intento de asimilación sintética de dos dimensiones al parecer no tan fáciles de combinar: el naturalismo empirista de Hobbes y el racionalismo grociano. (...) Nos encontramos, pues, ante una antropología que bebe en dos fuentes diversas, pero que quiere desembocar en una armonización sintética, haciendo de la 'socialitas' y de la 'imbecillitas' dimensiones ontológicamente radicadas en la naturaleza del hombre" (BRUFAU PRATS, J., La Actitud Metódica de Pufendorf y la Configuración
} 
nas tomadas de decisões. A incerta condição da "paz bastante duvidosa e pouco digna de confiança" do estado de natureza tornou problemática a transposição do "vínculo da afinidade compartilhada pelos homens" às alianças entre Estados. As alianças são buscadas entre aqueles que mantêm laços especiais pelo interesse comum, na maior parte das vezes determinada pela segurança interna contra o ataque de outros Estados. A razão disso é que nem sempre os acordos advêm dos ditames da razão, às vezes eles não estão isentos da interferência de elementos não racionais. Pufendorf reconhece a dificuldade do desafio. Mesmo assim, não aprova a guerra preventiva para limitar o poderio de Estados vizinhos, nem mesmo defende a ação unificada contra possíveis provocações externas, forçando-o a entrar no conflito bélico. Pufendorf se encaminha para a juridicização das relações internacionais, cujo discurso dos direitos assumiria papel decisivo no pensamento e práticas políticas de conselheiro do Grande Eleitor de Brandemburgo. ${ }^{32}$

Rompida a bela unidade do conceito de direito, como sinônimo de medida, dois sentidos claramente distintos se impõem à representação inevitá-

de la "Disciplina Juris Naturalis", p.56). Tese semelhante é defendida por Pierre Laurent. Se ele tem razão ao defender a tese de um "antropocentrismo moderado" na doutrina de Pufendorf, pode-se falar então que a sociabilidade, no seu sentido mais profundo, vincula estreitamente "l'être individuel de l'homme à son être en relation" (LAURENT, P., Pufendorf et la loi naturelle, Paris: Vrin, 1982, p. 109). Por princípio, Pufendorf recusaria um tratamento da condição humana a partir da sua individualidade absoluta, ela teria somente um valor relativo na medida em que dependeria da sociedade. Algumas passagens da obra de Pufendorf parecem corroborar as suspeitas de Brufau Prats, Laurent e vários outros comentadores. A título de ilustração, transcrevo a passagem De statu hominum naturali (texto de 1678) para efeito de comparação e justificação da difícil síntese: "Nam uti status naturalis propter conjunctionem hominum, tum ex similitudine naturae, tum ex mutua indigentia, tum ex dictato legis naturalis pacem ingerentis resultantem, pro bello proprie dicto haberi nequit: ita idem ob malitiam hominum, cupidinumque et affectuum rectae rationi obluctantium vehementiam indolem pacis satis lubricae et infidae habebit. Sic ut ideo quemlibet nobis amicum praesumere debeamus, animumque gerere promptum ad officia pacis et humanitatis adversus quemlibet exercenda, qui ista admittere velit: et nihilominus salutis nostrae solicitam semper curam agere, eamque ita munire, quase aliorum amicitiae parum sit confidendum; nec unquam per fiduciam alienae probitatis aut innocentiae in supinam nos negligentiam relaxemus" (PUFENDORF, S., Samuel Pufendorf's On the Natural State of Men, The 1678 Latin Edition and English Translation (translated by M. Seidler) Lewiston: The Edwin Mellen Press, 1990, §18, p. 103). Pufendorf parece realmente propor algum tipo de meio-termo que equilibrasse os dois perfis. Salta aos olhos, porém, o impacto já citado do dualismo metodológico do autor: a natureza humana em geral não pode ser considerada má, mas os homens particulares que encontramos diante de nós são oportunistas e inconstantes. ${ }^{32}$ Sobre o direito de guerra e a guerra efetiva, Pufendorf parece refletir sobre as posições de Grotius ao menos em quatro pontos: a) a consideração da vantagem ou utilidade que um determinado Estado pode esperar de uma guerra; b) o desejo de um determinado Estado em aumentar o seu território e poder de influências sobre os demais; c) as exigências vinculadas ao dever de acabar uma guerra; d) o respeito dos tratados e convenções estabelecidos com outros Estados (cf. ZARKA, Y. C., Philosophie et politique à l'âge classique, Paris: PUF, 1998, p. 189-192). 
vel da equivocidade semântica do termo. ${ }^{33}$ Francisco Suárez não hesitou nem um pouco ao afirmar que o direito apresenta simultaneamente o sentido de lei (legem) e de poder (potestas) ou quase poder (dominium vel quasi-dominium). ${ }^{34}$ Hugo Grotius também o fez e reconheceu três sentidos à palavra direito: ora significa o justo, ora é uma qualidade moral, ora diz respeito à lei. Como Suárez, Grotius ressalta que dois sentidos dominam o conceito: o poder e a lei. No De jure belli ac pacis encontramos a sua caracterização do direito e definição dos sentidos e graus de importância: "A palavra direito nada significa mais aqui do que aquilo que é justo. Isto, num sentido mais negativo que afirmativo, de modo que o direito transparece como aquilo que não é injusto. Ora, é injusto o que repugna à natureza da sociedade dos seres dotados de razão". 35 "Há um significado de direito diferente do anterior, mas que dele decorre e que se refere à pessoa. Tomado neste sentido o direito é uma qualidade moral ligada ao indivíduo para possuir ou fazer de modo justo alguma coisa". ${ }^{36}$ "Há um terceiro significado da palavra direito, segundo o qual o termo é sinônimo da palavra lei, tomado no sentido mais amplo e que indica uma regra das ações morais que obrigam a quem é honesto". ${ }^{37}$

Em suma, os jurisconsultos modernos tomam aos estoicos a ideia que faziam do direito natural. Para eles, o direito natural é um direito comum a todos os homens e pode ser conhecido pela luzes da reta razão, pois está inscrito no princípio da sociabilidade. Segundo Grotius: "o direito natural nos é ditado pela razão que nos leva a conhecer que uma ação, dependendo se é ou não conforme à natureza racional, é afetada por deformidade moral ou por necessidade moral e que, em decorrência, Deus, o autor da natureza, a proíbe ou a ordena".$^{38}$ As máximas do direito natural são desse modo as obrigações, os preceitos e as regras de moral que a reta razão deduz da "natureza racional e sociável" do homem. ${ }^{39}$

\footnotetext{
${ }^{33}$ Cf. GOYARD-FABRE, S., Les embarras philosophiques du droit naturel, Paris: PUF, 2002 , p. 7.

${ }^{34}$ Cf. SÉRIAUX, A., Le droit naturel, 2 ed., Paris: PUF, 1999, p. 67. Suárez também apresenta no De Legibus os principais sentidos do termo ius e sua relação com lex. São três: o ius como iustum, o ius enquanto facultas, e o ius como gênero e a lex como uma de suas espécies (neste caso, em geral, segundo Suárez, "ius prout legem significat cum illa convertitur et tanquam synonyma reputantur", SUÁREZ, F., De Legibus ac Deo Legislatore, I, De Natura Legis, Madrid: C.S.I.C., 1971, I, II, §7, p. 28).

${ }^{55}$ GROTIUS, H., O Direito da Guerra e da Paz (De Jure Belli ac Pacis), Introdução de António Manuel Hespanha (Trad. de C. Mioranza) Ijuí: Editora UNIJUÍ/Fondazione Cassamarca, 2004, I, I, §3, p. 72-73.

${ }^{36}$ GROTIUS, H., O Direito da Guerra e da Paz (De Jure Belli ac Pacis), I, I, §4, p. 73.

${ }^{37}$ GROTIUS, H., O Direito da Guerra e da Paz (De Jure Belli ac Pacis), I, I, §9, p. 78.

${ }^{38}$ GROTIUS, H., O Direito da Guerra e da Paz (De Jure Belli ac Pacis), I, I, §1, p. 79.

${ }^{39}$ Retomemos as teses principais de Grotius. As três inovações do jurista foram, portanto, as seguintes: tratar a justiça como uma questão de observância e exercício de direitos individuais; separar da teologia o estudo dos direitos; desvencilhar a filosofia política da busca pela forma ideal de governo graças ao reconhecimento da possibilidade de existência de formas diversas e igualmente legítimas, criadas por diferentes povos, no exercício
} 
Quase tudo o que dissemos até agora foi necessário para removermos os obstáculos mais importantes que se colocam à compreensão da tese central de Pufendorf. Só agora podemos apreender o seu sentido exato. Detendose cuidadosamente nas obras de Grotius e Hobbes, Pufendorf questionou e corrigiu uma série de detalhes e pontos importantes de seus antecessores. Retomemos inicialmente o exemplo de Hobbes, e imediatamente após, o exemplo de Grotius.

Um dos pontos em que Pufendorf questionou Hobbes diz respeito à falta de rigor na atribuição de direitos aos homens no estado de natureza. Ele argumentou que o princípio mais importante do direito natural está no dever de cultivar e preservar a sociabilidade; ${ }^{40}$ esta obrigação implica a existência dos deveres numa tripla dimensão: diante de Deus, diante de si mesmo e diante dos outros homens. ${ }^{41}$ Mais ainda, enquanto indivíduo, todo homem deve observar que as suas ações produzem efeitos em outras pessoas, e mediante essa tríade de obrigações ele deve atuar de modo a se chegar à condição de elemento útil à sociedade. O primeiro dever de quem vive coletivamente está na busca incansável de todos os meios possíveis e imagináveis para não causar dano a nenhum outro. $\mathrm{O}$ homem também precisa eliminar os meios e as ocasiões propícias a provocar uma reação antissocial, isto é, devem atuar visando aos outros, respeitando a dignidade e a igualdade de cada um, e evitar qualquer tipo de injúria e dano aos demais: "que cada um estime e trate o outro como naturalmente igual a ele ou como igualmente homem". ${ }^{42}$ Esta possibilidade de convivência social ordenada, no entanto, só é possível se reconhecemos que nem toda aptidão natural para a realização de determinadas tarefas caracteriza-se propriamente como um direito, mas apenas "aquela que tenha algum efeito moral". Uma "aptidão natural", tal como a capacidade de colher ou de caçar, somente se torna um "verdadeiro direito" quando tem um efeito moral sobre outras criaturas da mesma espécie. Da mesma forma, não faz sentido atribuir a um ser humano o direito de colher as castanhas, a menos que essa atividade afete a situação moral de outros seres humanos de maneira que outros homens não possam impedi-lo, ou competir com ele, contra a

de seus direitos em diferentes circunstâncias. No entanto, Grotius foi um defensor da sociabilidade humana, o que levou a afirmar que a natureza não estabelece apenas as leis da justiça, mas também a "lei do amor". A observância desta lei, embora não seja "perfeitamente obrigatória e impositiva", é louvável, e sua desobediência talvez seja digna de reprovação. Grotius faz mesmo uma distinção entre direitos perfeitos e imperfeitos que expressaria bem a tese: os direitos perfeitos são impostos por meio de processo legal e do reconhecimento de sua necessidade pelo próprio indivíduo, os direitos imperfeitos por sua vez não são direitos absolutos sobre aquilo que é "meu", mas antes uma espécie de merecimento que faculta a um indivíduo receber assistência ou atenção.

${ }^{40}$ PUFENDORF, S., Gesammelte Werke, Band 4.1: De jure naturae et gentium (Liber primus - Liber quartus), II, III, §20.

${ }^{41}$ PUFENDORF, S., Gesammelte Werke, Band 2: De officio. Herausgegeben von Gerald Hartung, Berlin: Akademie Verlag, 1997, I, IV e I, V.

${ }^{42}$ PUFENDORF, S., Gesammelte Werke, Band 2: De officio, I, VII, $\$ 1$. 
vontade dele, no uso de tais objetos. Obviamente, seria absurdo tentar designar como um direito a aptidão cujo exercício todos os outros homens têm o direito de impedir. Que tipo de efeito, então, é necessário para que o exercício de uma aptidão dê margem ao surgimento de um direito? A resposta de Pufendorf é que nenhum "direito propriamente dito" pode surgir sem que os outros estejam submetidos a uma obrigação para com o suposto detentor do direito.

Pufendorf foi, portanto, um dos primeiros a perceber um aspecto importante dos direitos - ao menos dos direitos "verdadeiros" ou "propriamente ditos" -, a que podemos chamar de correlatividade entre direitos e deveres (na ciência jurídica, esta concepção é especificamente conhecida como bilateralidade do direito). Nenhum direito pode ser atribuído a uma pessoa sem que se atribua a outras, ao mesmo tempo, certos deveres correlativos de não-interferência. No que concerne aos direitos de propriedade, imediatamente vem à tona a pergunta: de onde vem esse dever de não-interferência? Pufendorf responde que, devido à "igualdade natural dos homens", tal dever ou obrigação não pode surgir sem o consentimento dos outros, seja este "expresso ou presumido". A propriedade é definida como um direito em que a substância da coisa pertence ao indivíduo de tal modo que ela não pode pertencer a nenhuma outra pessoa da mesma maneira.

Além de confirmar o trabalho de redução terminológica iniciado por Grotius, Pufendorf apresenta também alguns limites às teses do jurista holandês. No De jure naturae et gentium, ele defende que a comunidade originária tem um caráter negativo, pois o mundo não pertenceu na origem a ninguém e estava à disposição de todos, isto é, a "comunidade negativa" dos bens não excluía de antemão o uso das coisas contidas no mundo. Assim sendo, cauteloso em fundar na natureza os direitos de convenção, Pufendorf sublinha a existência de um direito natural, no qual correspondem as obrigações humanas, que se aplica ao direito de propriedade nascido do consentimento. Segundo o autor: "O direito do homem sobre as coisas, antes de todo ato humano, não deve ser concebido como um direito exclusivo, mas somente como um direito indeterminado, isto é, que naturalmente ninguém possui uma porção particular e pode se apoderar de tudo em detrimento dos outros". ${ }^{43}$

A diferença em relação a Grotius está no fato de Pufendorf acreditar categoricamente que a propriedade só pode ser instituída convencionalmente - a divisão inicial deve ser considerada como consensual, em vez de natural. Para ele, o direito de propriedade supõe um ato humano, uma convenção que exprime a vocação do homem na condução das coisas do mundo. A noção de propriedade é um direito subjetivo excludente que se opõe a

${ }^{43}$ PUFENDORF, S., Gesammelte Werke, Band 4.1: De jure naturae et gentium (Liber primus - Liber quartus), III, V, §3. 
terceiros; um direito pleno sobre a substância da coisa que passa a pertencer à pessoa e não pode mais ser usufruído simultaneamente por várias outras. “Ora, da propriedade flui um direito, pelo qual a substância, por assim dizer, de alguma coisa pertence tanto a um que não pode da mesma maneira pertencer totalmente a outro" ${ }^{44}$ Por esse motivo, a existência do acordo é fundamental, sem ele não seria possível conceber aos olhos de Pufendorf a redução lógica da propriedade à posse privada.

O domínio pressupõe, portanto, um ato e um acordo (coetus) tácito ou expresso dos homens. Se os homens têm o poder de amealhar os recursos naturais para a sua sobrevivência, tal como os animais, esse poder, porém, só se converte num "verdadeiro direito" (um "direito propriamente dito") quando é capaz de criar um efeito moral sobre o resto da humanidade sem causar danos irreparáveis e disputas sem fim. “Um direito capaz de criar um efeito moral sobre o resto da humanidade, de modo que os outros homens não possam usurpar ou concorrer contra as suas vontades, pode surgir apenas por meio de um pacto firmado pelos homens sobre a divisão ou distribuição dos bens". ${ }^{45}$ Esse primeiro acordo tácito que consistia no estabelecimento da propriedade privada mediante a ocupação foi seguido de outros mais detalhados e precisos. A comunidade negativa que a lei natural havia estabelecido originariamente extingue-se progressivamente na medida em que a razão orientou os homens à formação de sistemas de propriedades mais evoluídos que asseguravam a paz no estado de natureza. ${ }^{46}$ Os acordos surgiram na medida em que os pactos prévios se tornaram insuficientes para assegurar a paz que exigia a lei natural. ${ }^{47}$

${ }^{44}$ PUFENDORF, S., Gesammelte Werke, Band 4.1: De jure naturae et gentium (Liber primus - Liber quartus), IV, IV, §2. Cf. TULLY, J., A Discourse on Property. John Locke and his adversaries, Cambridge: Cambridge University Press, 1982, p. 72 e TUCK, R., Natural Rights Theories, p. 156-162.

${ }^{45}$ PUFENDORF, S., Gesammelte Werke, Band 4.1: De jure naturae et gentium (Liber primus - Liber quartus), III, V, §5.

${ }^{46}$ PUFENDORF, S., Gesammelte Werke, Band 4.1: De jure naturae et gentium (Liber primus - Liber quartus), IV, VI-VII.

${ }_{47}$ Para Pufendorf, o emprego desigual do trabalho na obtenção das coisas necessárias para a sobrevivência dos indivíduos engendrou numerosas disputas, por isso a necessidade de outras formas negociadas para a estabilização das relações e restabelecimento da ordem segura das coisas. Uma vez que a maioria das coisas requer trabalho e cultivo, o homem que não gastou o mínimo de energia necessária para transformá-las em objetos de uso, não poderia reivindicar os mesmos direitos do indivíduo que contribuiu com a sua força de trabalho em torná-las bens consumíveis. Desse modo, as fórmulas contratuais estabelecidas pelos homens deviam aproximar-se paulatinamente do reconhecimento do status de propriedade que melhor se acomodasse a essa realidade, pois a propriedade era antes de tudo uma instituição cujo fim devia facilitar a preservação da paz. Pufendorf, assim, apreciou a importância do trabalho no desempenho do processo de geração do domínio privado, mas não foi capaz de reconhecer-lhe também o efeito moral que tornava possível articular uma justificação autônoma da propriedade (cf. BUCKLE, S., Natural Law and the Theory of Property. Grotius to Hume, Oxford: Clarendon Press, 1991, p. 101). Sua crença no pacto é demasiado forte para deixá-la de lado, uma vez que apenas 
Em suma, há uma boa razão para que as coisas pertençam a determinadas pessoas e não a outras, razão que Pufendorf atribui, a exemplo de Locke, ao trabalho. No entanto, diferentemente do autor inglês, o seu efeito de exclusão (não-interferência) de terceiros exige, para que possa surtir plenos efeitos morais, a confirmação de um pacto entre os envolvidos. Mesmo que seja um pacto tácito ou presumido.

Pufendorf também utilizou e elaborou a distinção de Grotius entre direitos perfeitos e imperfeitos. Para este autor, a diferença reside na obrigatoriedade dos direitos perfeitos e na não-obrigatoriedade dos imperfeitos. Estes descrevem o objeto da justiça atributiva, deixando claro que se deve considerar um direito imperfeito como algo semelhante a um direito legal ou perfeito, exceto que, em sua maior parte, somente este último, e não o primeiro deveria ser aplicado coercitivamente por meio de decisão política. $\mathrm{O}$ autor descreve a diferença mais geral entre os direitos nestes termos: "É menos imperativo que [os direitos imperfeitos] sejam observados em relação aos demais do que os direitos perfeitos e, por isso, é razoável que os direitos perfeitos possam ser mais rigorosamente impostos que os imperfeitos, pois é tolice prescrever um remédio que é muito mais problemático e perigoso que a própria doença" ${ }^{48}$ Além disso, ele conclui, os direitos imperfeitos são usualmente "deixados por conta do senso de decência e da consciência de cada pessoa". ${ }^{49}$ Pufendorf afirma que há também diferenças características no grau de especificidade e nas funções dos dois tipos de direito. Direitos perfeitos são aqueles honrados pela realização ou pela omissão de tipos específicos de ação por parte de outros indivíduos. Por exemplo, direito perfeito à vida tem como correlativo o dever de não matar, e direito perfeito de esperar que o outro cumpra sua promessa tem o correlativo o seu dever de cumpri-la; porém, o direito imperfeito à gratidão ou à assistência em caso de calamidade não tem como correlativo um dever tão específico a ponto de se levantar a questão sobre se a realização deste "é igual àquilo, ou melhor que aquilo, que o causou". Essa diferença reflete outra mais profunda, subjacente, entre as leis "que conduzem à mera existência da sociedade" - e criam direitos perfeitos, precisos e obrigatórios - e as que conduzem apenas "a uma existência melhor". ${ }^{50}$

a vontade pode criar um verdadeiro direito, um poder com efeitos morais que fizesse frente aos outros homens no âmbito do estado de natureza (cf. PUFENDORF, S., Gesammelte Werke, Band 4.1: De jure naturae et gentium (Liber primus - Liber quartus), IV, IV, §6).

${ }^{48}$ PUFENDORF, S., Gesammelte Werke, Band 4.1: De jure naturae et gentium (Liber primus - Liber quartus), I, VII, §7.

49 Ibidem.

50 A distinção proposta por Pufendorf foi desenvolvida por Christian Thomasius e pelos pensadores da sua escola na diferença entre obrigação interna e obrigação externa, em que a esta corresponde a exterioridade, o direito, a imposição e a soberania, e a outra remete para a interioridade, a ética, o conselho e a virtude (THOMASIUS, C., Fundamenta iuris naturae et gentium, Scientia Verlag Aalen, 1979, I, V, §§XVII-XXI, p. 149).

Síntese, Belo Horizonte, v. 37, n. 118, 2010 
Enquanto para Grotius os homens são sociáveis por natureza, a visão de Pufendorf, como a de Hobbes, é menos otimista. ${ }^{51}$ Mas isso não o impediu de ver no desejo humano de segurança uma compensação para nossa predisposição inata para o vício, uma vez que, para garantir sua segurança, é necessário que o homem seja sociável. Esta conclusão lançou as bases daquilo a que ele chamou de "lei natural fundamental": preservar e cultivar a sociabilidade. Mas cultivar a socialitas significa ultrapassar a condição de igualdade natural e sair do estado em que nos encontrávamos numa relação pré-política. Significa criar as condições necessárias de sua plena realização no estado civil onde impera a ordem política e as suas instituições básicas.

Desse modo, o Estado (civitas) é constituído para superar a situação de guerra em que se degenerou o estado de natureza e oferecer segurança aos homens. É preciso construir a proteção entre eles e para eles: “Portanto, a causa genuína e principal que levaram alguns pais de famílias perdidos em sua liberdade natural a constituírem os Estados, foi para protegerem dos males provenientes do homem que ameaçavam o homem". ${ }^{52}$ É nos Estados que "se encontra um remédio imediato, bem ajustado às características dos homens". ${ }^{53}$

Pufendorf defende o Estado moderno como a realização perfeita do desenvolvimento moral da humanidade, o lugar certo da superação do afastamento entre a sociedade civil artificial - construída pelos homens segundo

Desta mesma separação entre interno e externo, virtude e direito, imposição e conselho, amor e coação Thomasius elaborou, depois, também a divisão da filosofia prática em três âmbitos de experiência referentes a três diferentes princípios morais: a honestidade, o decoro e a justiça (THOMASIUS, C., Fundamenta iuris naturae et gentium, I, IV, §§LXXIIILXXVI, p. 137-138 e I, VI, §§XL-XLII, p. 177; cf. SCHNEIDERS, W., Naturrecht und Liebesethik. Zur Gescichte der praktischen Philosophie im Hinblick auf Christian Thomasius, Hildesheim: Georg Olms Verlag, 1971, p. 268-273).

${ }^{51}$ Aqui, porém, cumpre ressaltar a importância da filosofia política de Hobbes e o influente papel desempenhado por ela no pensamento de Pufendorf. Vários trabalhos dão conta disso, senão para defender a condição de discípulo direto (posições de PALLADINI, F., Samuel Pufendorf Discepolo di Hobbes. Per uma reinterpretazione del giusnaturalismo moderno, Bologna: Società Editrice Il Mulino, 1990, MANCINI, O., Diritto naturale e potere civile in Samuel Pufendorf, in DUSO, G. (org.) Il Contratto Sociale nella Filosofia Politica Moderna, $2^{\mathrm{a}}$ ed. Milano: FrancoAngeli, 1998, p. 109-148, SCATTOLA, M. Thomas Hobbes, Samuel Pufendorf e l'insegnamento del diritto pubblico universale, in FERRONATO, M. (org.) Dal "De Jure Naturae et Gentium" di Sameul Pufendorf alla Codificazione Prussiana del 1794, p. 61-92) ao menos como um leitor atento que propôs retificá-lo sem se afastar do universo político do filósofo de Malmesbury (BRUFAU PRATS, J., La Actitud Metódica de Pufendorf y la Configuración de la "Disciplina Juris Naturalis", 1968, FIORILLO, V., Tra Egoísmo e Socialità. Il Giusnaturalismo di Samuel Pufendorf, Napoli: Jovene Editore, 1992).

52 PUFENDORF, S., Gesammelte Werke, Band 4.2: De jure naturae et gentium (Liber quintus - Liber octavus), Herausgegeben von Frank Böhling, Berlin: Akademie Verlag, 1998, VII, II, §1.

${ }^{53}$ PUFENDORF, S., Gesammelte Werke, Band 2: De officio, II, V, §9. 
suas necessidades e interesses - e a necessidade moral. O Estado deve ser entendido como criado para nossos fins, nossa proteção e defesa. Pode-se dizer que a adequação dessa forma de organização, como também de suas correspondentes formas de socialização, é determinada pelo seu sucesso em satisfazer nossos fins. Mas também enobrece a união dos homens e de seus esforços em instaurar e efetivar o direito natural. Sua origem está em Deus e sua finalidade em governar a humanidade. O Estado no sistema de Pufendorf é o ponto final da sociabilidade, sua realização plena, e como tal exige um direito que regule e ordene o comportamento dos cidadãos. ${ }^{54}$

\section{Conclusão}

É Samuel Pufendorf defensor de uma ciência jurídica desprovida de bases filosóficas consistentes, como sustentou Leibniz, ou a sua obra não teria sido "o primeiro sistema autêntico de teoria geral do Direito", como definiu Franz Wieacker? Para encerrar o artigo, não podemos mais adiar o exame das tentativas que transformaram Samuel Pufendorf no jurista médio que parece "não ter determinado corretamente nem o fim e o objetivo do direito natural, nem tampouco sua causa eficiente", ${ }^{55}$ ou no pai da teoria geral do direito. Responder às questões do dilema posto pela tradição interpretativa e às objeções sobre a importância de seus escritos. Algumas hipóteses podem ser levantadas sobre a carta de Leibniz e "os sinais de uma mente penetrante, uma mente que estava longe de se deixar dominar pelo julgamento de outros homens". ${ }^{56}$

No prefácio ao seu compêndio De officio Pufendorf quis esclarecer a relação existente entre direito natural e teologia moral, entre razão e revelação, entre imanência e transcendência: "É manifesto que três são as fontes das quais os homens recebem o conhecimento dos seus deveres, isto é, daquilo que nesta vida eles devem fazer porque é honesto, e daquilo que devem evitar porque é torpe: da luz da razão, das leis civis e de uma especial revelação da divindade".$^{57}$ Da luz da razão provêm os deveres universalmente comuns a todos os homens, das leis civis as incumbências respeitantes aos cidadãos de determinada cidade, da revelação as obrigações dos cristãos. Aos três âmbitos correspondem três diferentes disciplinas do saber

\footnotetext{
${ }^{54}$ PUFENDORF, S., Gesammelte Werke, Band 4.2: De jure naturae et gentium (Liber quintus - Liber octavus), VII, III, §2.

${ }^{55}$ LEIBNIZ, G. W., Jugement d'un Anonyme, in Les devoirs de l'homme et du citoien, p. 388.

${ }^{56}$ BARBEYRAC, J., Jugement d'un Anonyme, in Les devoirs de l'homme et du citoien, p. 380 .

${ }^{57}$ PUFENDORF, S., Gesammelte Werke, Band 2: De officio, Lectori benevolo, p. 5.
} 
humano, o direito natural, o direito civil e a teologia moral, que podem ser concebidas como três esferas concêntricas. $O$ direito natural é uma forma de conhecimento próprio do homem enquanto ser racional; o direito civil intervém em todos os conteúdos indiferentes ao direito natural, disciplinando-os conforme o seu arbítrio; a teologia moral regula, por fim, com proibições ou ordens as matérias deixadas indeterminadas pelo direito civil..$^{58}$

Neste quadro epistemológico, "a doutrina do direito civil pressupõe o direito natural como disciplina mais geral e, assim, se o direito civil contém algo sobre o qual o direito natural nada diz, nem por isso é necessário acreditar que haja contradição". ${ }^{59} \mathrm{O}$ mesmo se deve pensar da teologia, na qual podem ocorrer duas situações. Pode, com efeito, acontecer de a teologia ensinar algo que a nossa razão não compreende e o direito natural nada falar a respeito, como o dogma da Trindade, e então não será necessário pensar que aqui a revelação acrescenta um conteúdo indiferente ao direito natural. Mas também pode acontecer que o direito natural, para chegar às suas próprias conclusões, formule suposições que contradigam os ensinamentos da teologia. Por exemplo, o direito natural pressupõe que o homem não possua uma ideia inata do bem, ou então, imagina a condição original dos homens muito diferente de como aparece descrita na página bíblica. Neste caso, o direito natural procede - defende Pufendorf - "abstraindo" das Sagradas Escrituras, pois estas recebem o seu conhecimento "da revelação peculiar de Deus, que a razão, por si só, não pode alcançar" ${ }^{60}$ Quando se manifesta um potencial conflito a razão prescinde, portanto, do ensinamento da teologia e faz valer apenas a sua própria hipótese. Esta, de fato, contém um princípio universal, eficaz a um nível "mais abstrato" e para um número de casos mais vastos, enquanto que a teologia enuncia verdades que valem apenas para os cristãos e, por isso, acrescentam algo mais às regras vigentes dos homens. A crítica de Leibniz recai justamente sobre este ponto crucial. Crítica confirmada pelas retificações de Barbeyrac, que acusaram o direito natural de Pufendorf de estar em falta, pois aceita o ponto de vista de um ateu e exclui na sua dedução a imortalidade da alma e a possibilidade de os malvados serem punidos no Além. ${ }^{61}$ Desse modo, reduzia-se a vida humana à mera sobrevivência do

\footnotetext{
58 PUFENDORF, S., Gesammelte Werke, Band 2: De officio, Lectori benevolo, p. 5-6.

59 PUFENDORF, S., Gesammelte Werke, Band 2: De officio, Lectori benevolo, p. 5.

${ }^{60}$ PUFENDORF, S., Gesammelte Werke, Band 2: De officio, Lectori benevolo, p. 6.

${ }^{61}$ LEIBNIZ, G. W., Jugement d'un Anonyme, in Les devoirs de l'homme et du citoien, $\mathrm{p}$. 389-392, BARBEYRAC, J., Jugement d'un Anonyme, in Les devoirs de l'homme et du citoien, p. 392-396. A nota de Barbeyrac (BARBEYRAC, J., Préface du Traducteur, in Les devoirs de l'homme et du citoien, nota I, p. XL-XLI) expressa importante afastamento da concepção de Pufendorf, ao insistir na probabilidade do castigo divino estar aberta à razão e pertencer ao direito natural. Em outras palavras, Barbeyrac procura suspender a restrição do direito natural a esta vida e com isso a tentativa de Pufendorf de construir o direito natural como uma ética secular em que impera a "civil philosophy" (HUNTER, I., Rival Enlightenments, p. 128).
} 
corpo e renunciava-se a todo e qualquer vínculo com uma dimensão transcendente. ${ }^{62}$ Contra observações deste tipo Pufendorf objetava, por sua vez, que não é necessário recorrer a Deus para fundar os deveres do homem e que existe uma obrigação propriamente dita, independente não apenas da imortalidade da alma, mas também da existência de Deus ${ }^{63}$.

O direito natural e a sua razão incluem tudo aquilo que nós sabemos da vida humana sobre a Terra e, por isso, quando se trata de explicar o agir do homem, ou a teologia é coerente com o direito natural ou tem de fazer valer as suas afirmações apenas como especificações particulares, válidas para os cristãos, mas não para todos os homens. A teologia não pode intervir no mundo humano enquanto tal, e regula um âmbito separado, externo, ulterior, enquanto que o direito natural raciocina como se nem a religião nem Deus existissem. ${ }^{64}$ Esta exclusão do princípio religioso foi o momento essencial do nascimento do direito natural moderno e sobre este ponto desencadeou-se a polêmica que opôs durante muitos anos Pufendorf aos teólogos de Leipzig. ${ }^{65}$

62 HUNTER, I., Rival Enlightenments, p.129.

${ }^{63}$ A tese parece confirmada no Prefácio ao De officio: "Illud porro discrimen longe maximum est, quod finis disciplinae juris naturalis tantum ambitu hujus vitae includatur, adeoque ea hominem formet, prout hanc vitam cum aliis sociabilem exigere debeat. (...) Inde \& juris naturalis scita ad forum duntaxat humanum adaptantur, quod ultra hancce vitam sese non extendit; quae ipsa multis in partibus prave ad fórum divinum adplicantur, circa quod Theologiae máxime curae est" (PUFENDORF, S., Gesammelte Werke, Band 2: De officio, Lectori benevolo, p. 6).

${ }^{64}$ De certo modo, o caminho foi aberto pela polêmica iniciada por Grotius em seu Prolegômeno, em especial ao escrever: "Et haec quidem quae iam diximus, locum aliquem haberent etiamsi daremus, quod sine summo scelere dari nequit, non esse Deum, aut non curari ab eo negotia humana" (GROTIUS, H., De Iure Belli ac Pacis Libri Tres. In Quibus Ius Naturae Et Gentium, Item Juris Publici Praecipua Explicantur. Cum Annotatis Auctoris, Edited by P. C. Molhuysen. Lugduni Batavorum: Apud A. W. Sijthoff, 1919, Prolegomena, §11, p. 7, grifos de minha autoria). Aqui, também, a recepção crítica de Grotius varia conforme a ênfase concedida às partes da argumentação. Se considerarmos tão só o significado de etiamsi daremus non esse Deum, o impacto é surpreendente, pois de fato inicia o percurso já presente em Pufendorf e que foi concluído em Thomasius. Se considerarmos, no entanto, a ressalva contida no parágrafo, que alerta para o absurdo da hipótese da inexistência de Deus, a tese grotiana deve ser relativizada. Embora não haja acordo entre os comentadores, a semente da laicização do direito natural foi plantada e os frutos não tardaram a desabrochar.

${ }^{65}$ A polêmica está resumida na sua obra Eris Scandica. Na realidade, uma coletânea de textos cujo teor foi esclarecer as posições de Pufendorf diante do debate com seus contemporâneos (cf. a introdução de Fiammetta Palladini à edição da Akademie, 2002, p. VIIXXI). A separação entre teologia e direito teorizada por Pufendorf foi aperfeiçoada por Christian Thomasius, seu principal seguidor na Alemanha do final do século XVII. Além da defesa contra os ataques de Valentin Alberti, que havia criticado duramente as teses de Pufendorf, Thomasius levou às extremas consequências o seu pensamento (cf. AHNERT, T., Religion and the Origins of the German Enlightenment. Faith and the Reform of Learning in the Thought of Christian Thomasius, Rochester: University of Rochester Press, 2006, p. 84-88). Nos Institutiones Iurisprudentiae Divinae, de 1688, Thomasius demonstrou que é impróprio definir o direito natural como lei eterna e presente desde sempre em Deus, pois de tal modo atribui-se um conteúdo material, e limitado, à infinita 
Há, porém, o lado positivo desta separação, a apresentação da versão racionalizada (independente da Revelação e do dogma) do conteúdo dos preceitos da segunda Tábua do Decálogo. Deus é considerado o legislador que funda a obrigação moral e jurídica (esta segunda emanando da primeira) no estrito limite das normas necessárias à realização dos fins naturais do homem, considerados objetivamente como orientados à segurança ou à conservação da vida humana e dos meios que lhes são necessários. Nesta configuração, a lei é para o homem que se submete a condição de moralidade na ordem ética, de cidadania na ordem política e de salvação na ordem religiosa. Um mesmo esquema lógico associando o legislador, a lei e o sujeito da obrigação se encontra na moral, na política e na teologia. A questão da justiça não é mais aquela da finalidade a se alcançar, mas da legitimidade a se respeitar, aquela de Deus e do poder humano. Assim, ao definir a lei (religiosa, natural ou moral humana ou jurídica) como comando de um superior, distinguindo com clareza o mundo dos fatos e dos valores (pela dicotomia dos seres físicos e dos seres morais), e esboçar a teoria da obrigação moral, independente dos "motivos sensíveis", Pufendorf forneceu a expressão mais completa desta inspiração moderna.

Endereço do Autor:

Departamento de Filosofia - Bloco IV

Faculdade de Artes, Filosofia e Ciências Sociais

Universidade Federal de Uberlândia

Av. João Naves de Ávila, 2121

38400-902 Uberlândia - MG

e-mail: felipesahd@yahoo.com.br

razão divina (THOMASIUS, C., Institutiones jurisprudentiae divinae, Scientia Verlag Aalen, 1963, I, IV, §21, p. 76-77). A reta razão não pode, por isso, ser algo de material, mas apenas uma faculdade de raciocínio formal e vazia, uma capacidade de calcular, "ligar um termo a outro" (THOMASIUS, C., Institutiones jurisprudentiae divinae, I, II, $\$ 66$, p. 44). O princípio do direito natural deverá ser procurado no "homem em si próprio", considerado na condição específica em que se encontra após o pecado original, isto é, sem qualquer referencia a Deus. Este estado deve ser imaginado como uma ficção, que pode também ser contrária aos ensinamentos das Sagradas Escrituras, mas que, avançando uma proposição hipotética, gera uma série de conclusões verdadeiras segundo um "nexo necessário". Do mesmo modo procede ao adepto do direito natural, que para dar fundamento universal à sua doutrina não pode limitar-se às certezas dos cristãos, mas deve hipoteticamente aceitar o ponto de partida mais vasto dos pagãos ou dos ateus (THOMASIUS, C., Institutiones jurisprudentiae divinae, Dissertatio prooemialis, §52, p. 47-50; I, IV, §§35-38, p. 79-80), e imagina como seria o mundo sem Deus (THOMASIUS, C., Fundamenta iuris naturae et gentium, Caput prooemiale, §XXIX, p. 21-22; cf. SCHNEIDERS, W., Naturrecht und Liebesethik, p. 97-116, AHNERT, T., Religion and the Origins of the German Enlightenment, p. 88-93). 